\title{
ANALISIS KEBUTUHAN TULANGAN PADA BALOK BETON BERTULANG TAMPANG T MENGGUNAKAN PROGRAM SAP 2000
}

\author{
Ngudi Hari Crista ${ }^{1^{*}}$, Trias Widorini ${ }^{2}$, Bambang Purnijanto ${ }^{3}$ \\ 1, 2, 3 Jurusan Teknik Sipil Fakultas Teknik Universitas Semarang \\ Jl. Soekarno Hatta, Tlogosari, Semarang, Jawa Tengah, Indonesia \\ *e-mail : haringudiharicrista@yahoo.co.id
}

\begin{abstract}
Beams as one of the components of a building structure have a very important role in carrying the burden on it. Reinforced concrete beams with $T$ sections are beams that are widely used in building floor systems. The use of computer programs is considered to be quite effective in terms of time, cost and equipment used but it is necessary to know the level of accuracy of T-beam concrete analysis and design using a computer program, SAP 2000. To compare the results of analysis and design with the SAP 2000 program the results used obtained according to SNI 2002. Based on the results of calculations with the SAP 2000 program and according to SNI 2002, there were differences in results in terms of the longitudinal reinforcement area needed. This is due to the default SAP 2000 model of the beam with wing wing position not located on the upper side of the beam but on the beam weight line and there is an overlap on the beam and plate which affects the dead weight of the structural components.
\end{abstract}

Keywords : T beam; SAP 2000

\begin{abstract}
ABSTRAK
Balok sebagai salah satu komponen struktur gedung mempunyai peranan yang sangat penting dalam memikul beban diatasnya. Balok beton bertulang dengan penampang $T$ merupakan balok yang banyak digunakan pada sistem lantai bangunan. Penggunaan program komputer dianggap cukup efektif dalam hal waktu, biaya dan peralatan yang digunakan namun perlu diketahui berapa tingkat akurasi analisis dan desain balok beton tampang $\mathrm{T}$ dengan menggunakan program komputer yaitu SAP 2000. Sebagai pembanding untuk hasil analisis dan desain dengan program SAP 2000 digunakan hasil yang diperoleh menurut SNI 2002. Berdasarkan hasil perhitungan dengan program SAP 2000 dan menurut SNI 2002, terdapat perbedaan hasil dalam hal luas tulangan memanjang yang dibutuhkan. Hal disebabkan oleh model default SAP 2000 balok dengan sayap posisi sayap tidak terletak pada sisi atas balok tetapi pada garis berat balok dan terdapat bagian overlap pada balok dan pelat yang berpengaruh pada berat mati komponen struktur.
\end{abstract}

Kata kunci : balok T, SAP 2000 


\section{PENDAHULUAN}

Balok sebagai salah satu komponen struktur gedung mempunyai peranan yang sangat penting dalam memikul beban diatasnya yang berupa beban mati, beban hidup dan berat plat lantai. Balok adalah komponen struktur yang menyalurkan beban-beban tributary dari plat lantai ke kolom penyangga. Balok beton yang dicor monolit dengan elemen plat disebut balok $T$ atau balok $\mathrm{L}$. Balok $T$ dan balok $L$ adalah bentuk penampang balok bukan segi empat yang paling sering digunakan.

Pada perhitungan struktur yang kompleks dan rumit perlu adanya alat bantu perhitungan guna mempermudah pengerjaan dan memperkecil resiko kesalahan. Alat bantu yang dimaksud disini tak lain adalah program komputer. Program SAP merupakan salah satu program analisis dan desain struktur yang telah dipakai secara luas diseluruh dunia (Satyarno dan Nawangalam, 2012).

Penggunaan program komputer dianggap cukup efektif dalam hal waktu, biaya dan peralatan yang digunakan namun perlu diketahui berapa tingkat akurasi analisis dan desain balok beton tampang $\mathrm{T}$ dengan menggunakan program komputer yaitu SAP 2000.Tujuan penelitian ini untuk membandingkan jumlah tulangan yang dibutuhkan balok beton bertulang tampang $T$ menggunakan program komputer SAP 2000 dengan SNI 2002. Dari hasil penelitian ini diharapkan dapat diketahui tingkat akurasi pemodelan dengan menggunakan program SAP 2000 untuk analisis dan desain balok beton tampang $\mathrm{T}$.

\section{TINJAUAN PUSTAKA}

Program komputer rekayasa (SAP 2000, ETABS dan lain-lain) berbeda dengan program komputer umum (Word, Excel), karena pengguna program komputer rekayasa dituntut untuk memahami latar belakang metode penyelesaian dan batasan-batasan yang dihasilkan dari program tersebut. Secanggih apapun program komputer keputusan tetap ada di tangan manusia yang memakainya, apakah model sudah mampu mencerminkan kondisi yang sebenarnya. Karena yang perlu diingat adalah program komputer tersebut hanyalah alat bantu saja (Satyarno dan Nawangalam, 2012).

Beberapa penelitian yang telah dilakukan tentang balok beton bertulang dengan menggunakan berbagai program computer seperti Widorini (2015), meneliti tentang Analisis prilaku lentur balok beton bertulang tampang $T$ menggunakan Response-2000. Hasil penelitian tersebut menunjukkan kapasitas daya dukung beban untuk benda uji berdasarkan pengujian dengan hasil analisis menggunakan program response-2000 menunjukkan tingkat kecocokan yang cukup tinggi.

Yanuar, (2015) melakukan pengujian balok bertulang tampang $\mathrm{T}$ yang diperkuat wire rope pada daerah momen negative dengan analisis menggunakan Response-2000 dengan metode pias, kemudian menganalisis gaya -gaya yang bekerja sampai tercapai keseimbangan sehingga dapat ditentukan kapasitasnya. Hasil analisis menunjukan bahwa kurva hubungan beban- lendutan untuk semua balok berdasarkan analisis response-2000 memiliki pola yang mendekati kurva hubungan beban-lendutan hasil pengujian. Namun demikian terdapat perbedaan pada kemiringan kurva dimana hal tersebut dapat disebabkan oleh adanya anggapan lekatan sempurna (perfect bond) pada program Response-2000, yang sama juga berlaku pada analisis metode pias. 
Handayani,Tri (2018) Telah melakukan analisis lendutan balok beton yang diberi beban dari sebuah gedung. Analisis dilakukan menggunakan software berbasis finiteelement method (FEM) dan eksperimental dengan tujuan untuk mengetahui pengaruh jenis tumpuan dan tipe penampang balok terhadap lendutan.Dalam analisis menggunakan software FEM, lendutan balok dihitung menggunakan persamaan lendutan balok dengan dua tumpuan yang diasumsi sebagai penampang balok biasa dan penampang balok T. Selainitu, kondisi tumpuan balok diperhitungkan sebagai tumpuan sederhana dan tumpuan jepitjepit. Dalam evaluasi secara eksperimental balok beton dibebani sesuai SNI 2847 2013, dengan beban uji adalah air dan besarlendutan diukur dengan linear variable displacement transducer (LVDT). Perhitungan lendutan di tengah bentang dengan software berbasis FEM dengan asumsi balok $T$ dan tumpuan jepit-jepit pada eksperimen ini dapat disimpulkan bahwa lendutan balok beton hasil evaluasi menggunakan software FEM melalui perhitungan dengan asumsi penampang balok $\mathrm{T}$ dengan kondisi tumpuan jepit-jepit adalah yang paling mendekati lendutan hasil evaluasi secara eksperimental melalui uji beban.

\section{METODE PENELITIAN}

\section{Tahapan Penelitian}

Tahapan penelitian yang dilakukan adalah:

b. Kompilasi data dimensi Balok $\mathrm{T}$, properti material beton, berat dan mendefinisikan pembebanan.

a. Membuat visualisasi profil balok $T$ yang dimodelkan sebagai elemen Frame yang dengan membuat empat sampel bentang balok yang berbeda.

b. Menguji dan menganalisis dengan bantuan komputerisasi (SAP 2000 versi 14) dari empat sampel balok T dengan beban merata.

c. Temuan lenturan dari empat sampel.

d. Membuat simpulan dengan membandingkan hasil dari tinjauan keempat sampel tersebut dengan membandingkan hasil dari SNI 03-2847-2002 sehingga dapat diketahui jumlah penulangan yang dibutuhkan.

\section{Data Penelitian}

Data penelitian yang digunakan adalah:
a. Fungsi bangunan
b. Beban hidup
: rumah tinggal
c. Bahan bangunan
d. Berat jenis beton (wc)
: 2,00 kN/m2
e. Mutu beton ( $\mathrm{fc}^{\prime}$ )
: beton bertulang
f. Modulus elastisitas beton Ec
: $2,40 \mathrm{kN} / \mathrm{m} 3$
g. Mutu baja tulangan (fy)
: $20 \mathrm{MPa}$
h. Modulus elastisitas baja Es
$: 4700 \sqrt{ } \mathrm{fc}^{\prime}$
: $400 \mathrm{MPa}$
: $200000 \mathrm{MPa}$
i. Angka poison u
j. Panjang balok
k. Jarak antar balok
$: 0,20$
: $4 \mathrm{~m}, 5 \mathrm{~m}, 6 \mathrm{~m}$ dan $7 \mathrm{~m}$
: $3 \mathrm{~m}$
: $12 \mathrm{~cm}$
m. Kombiansi pembebanan
$: 1,2^{*} \mathrm{D}+1,6^{*} \mathrm{~L}$

Model sampel penelitian berupa balok beton tampang $\mathrm{T}$ seperti pada gambar 1. Balok yang akan diteliti yaitu balok tengah (balok dengan sayap pada kedua sisi). Jumlah sampel yang digunakan 4 buah (berbeda panjang bentangnya) : 


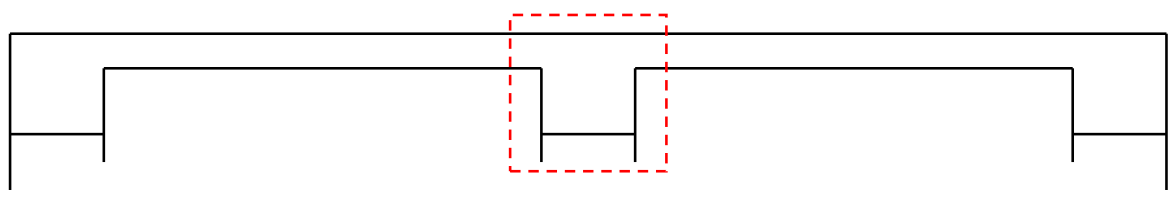

Gambar 1. Potongan melintang balok dan pelat lantai

\section{Tahapan Perhitungan}

a. Perhitungan dengan cara manual berdasarkan SNI 2002

- Analisis pembebanan.

- Perencanaan luas tulangan memanjang.

- Hasil yang diperoleh dengan cara hitungan tangan (dengan alat bantu Excel) digunakan sebagai acuan untuk meninjau hasil yang diperoleh bila menggunakan program SAP 2000.

- Langkah-langkah dalam melakukan perhitungan penulangan memanjang balok $\mathrm{T}$ dapat dilihat pada gambar 2 .

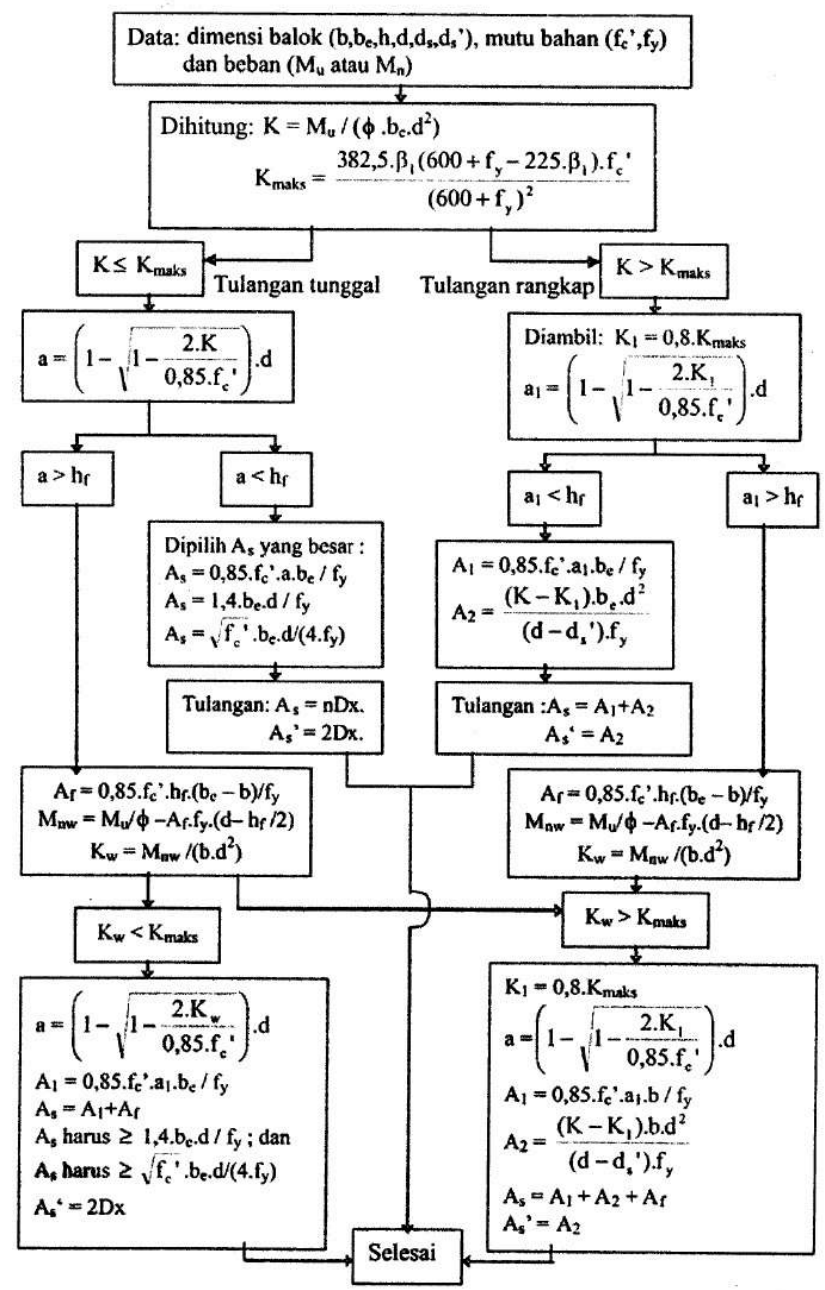

Gambar 2. Diagram alir penulangan balok $T$

Sumber : Asroni, 2010

b. Perhitungan dengan program SAP 2000

Pemodelan balok dengan sayap pada SAP 2000 dapat dilihat pada gambar 3. Langkah-langkah dalam melakukan analisis dan perencanaan 
tulangan dengan menggunakan program SAP 2000 dapat diuraikan sebagai berikut :

- Menentukan unit satuan.

- Menentukan (membuat) model struktur balok, pelat lantai dan tumpuan.

- Menentukan karakteristik bahan yang digunakan.

- Menentukan pembebanan pada pelat lantai.

- Analisis gaya-gaya dalam dan deformasi.

- Perencanaan tulangan memanjang (berdasarkan ACl)

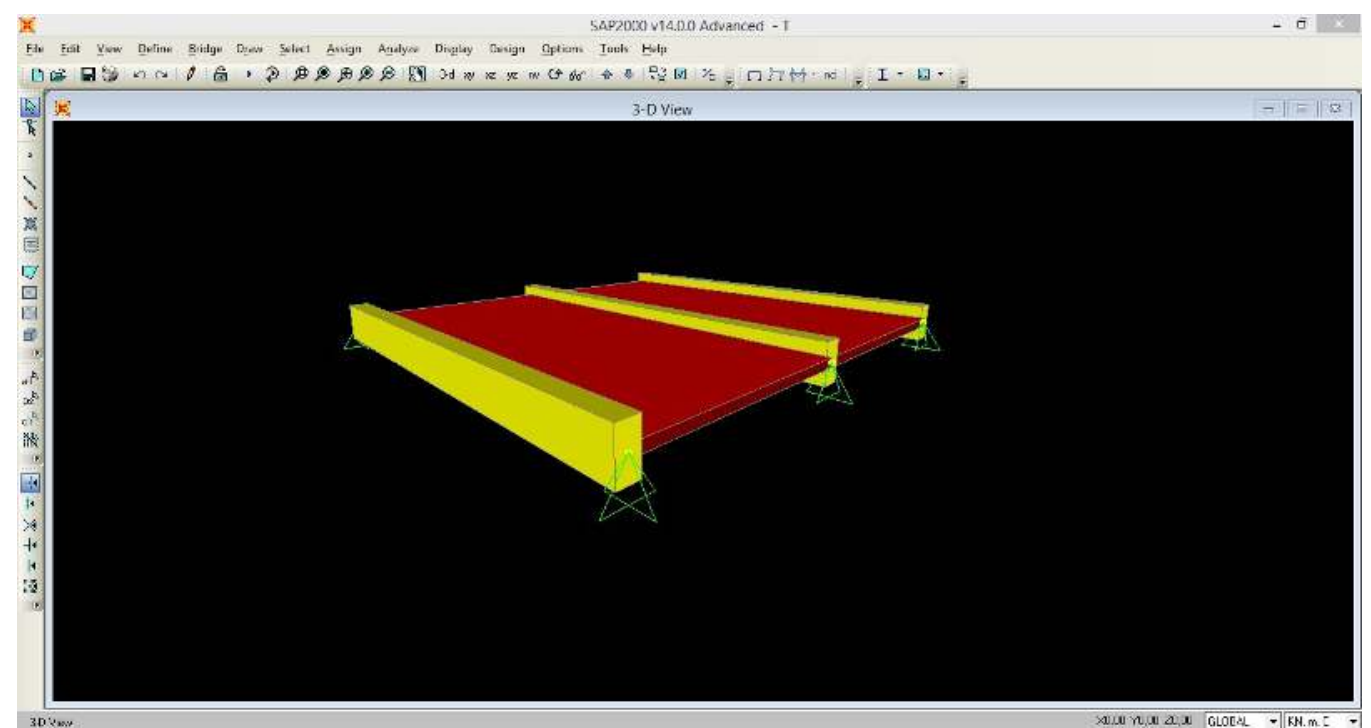

Gambar 3. Pemodelan balok dengan sayap pada SAP 2000

\section{HASIL DAN PEMBAHASAN}

Dari hasil penelitian ini didapat luasan minimum penulangan memanjang yang dibutuhkan untuk balok bertulang tampang $T$ dengan perbedaan panjang bentang. Hasil tersebut dapat dilihat pada tabel 1.

Tabel 1. Perbandingan Luasan Minimum Penulangan Memanjang Yang Dibutuhkan

\begin{tabular}{cccc}
\hline $\begin{array}{c}\mathrm{L} \\
(\mathrm{m})\end{array}$ & $\begin{array}{c}\mathrm{SNI} 2002 \\
\left(\mathrm{~mm}^{2}\right)\end{array}$ & $\begin{array}{c}\text { SAP 2000 } \\
\left(\mathrm{mm}^{2}\right)\end{array}$ & $\begin{array}{c}\text { SELISIH } \\
(\%)\end{array}$ \\
\hline 4,00 & 2197,207 & 1775 & 19,21 \\
5,00 & 2518,522 & 2590 & 2,84 \\
6,00 & 3170,152 & 3374 & 6,43 \\
7,00 & 3449,564 & 4149 & 20,28 \\
\hline
\end{tabular}

Berdasarkan hasil penghitungan penulangan dengan cara hitungan tangan menurut SNI 2002 dan SAP 2000 terdapat perbedaan yang signifikan dalam hal luas tulangan memanjang yang dibutuhkan. Hal ini bisa terjadi kemungkinan disebabkan oleh model default SAP 2000 balok dengan sayap dimana posisi sayap tidak terletak pada sisi atas balok tetapi pada garis berat balok (seperti terlihat pada gambar 3). Terdapat bagian overlap pada balok dan pelat tersebut sehingga berpengaruh pada berat mati komponen struktur. Karena 
perbedaan ini bisa mengakibatkan perbedaan hasil analisis struktur dan desain penulangan balok.

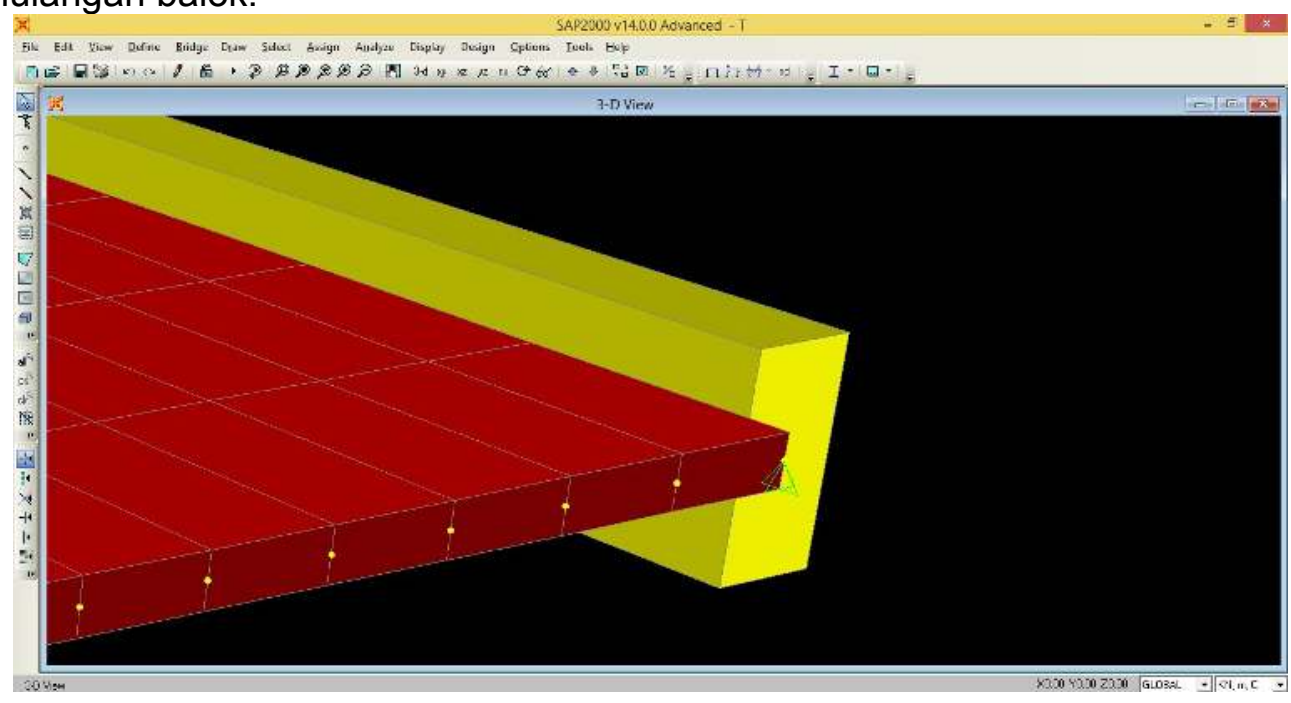

Gambar 3. Overlap balok dengan pelat pada SAP 2000

\section{KESIMPULAN}

Dari hasil penelitian ini adalah terdapat perbedaan hasil analisis dan desain antara perhitungan cara manual dan program SAP 2000. Perbedaan luaran yang terjadi bisa sedikit atau besar tergantung ketelitian cara memasukan data.

\section{DAFTAR PUSTAKA}

Anonim. (2002). Tata Cara Perhitungan Struktur Beton untuk Bangunan Gedung (SNI 03-2847-2002). BSN.

Asroni, A. (2010). Kolom, Fondasi dan Balok T Beton Bertulang. Yogyakarta : Graha IImu

Nur, K. S. (2010), Analisis Geser Balok-T Beton Bertulang Berlubang Memanjang Dengan Menggunakan Metode Elemen Hingga Nonlinier. Jurnal Inersia. 6(2), 111-120.

Satryano, I dan Nawangalam, P. (2012), Belajar SAP2000 Cepat-Tepat-Mahir Seri 1. Yogyakarta : edisi kedua, Zamil Publishing.

Widorini, Trias dan Purwanto. (2015). Analisis Perilaku Lentur Balok Beton Bertulang Tampang T Menggunakan Response-2000, Jurnal Teknika, 10(1), 1-6.

Handayani, Tri dan Irawati yudi. (2018). Analisa Lendutan balok beton secara eksperimental dan Metode Elemen Hingga sesuai SNI 2847:2013, PISSN 1410-3680/E-ISSN 2541-1233

Haryanto, Yanuar. Satyarno,Iman dan Sulistyo Djoko (2015). Analisis Daya Dukung Beban Balok Beton Bertulang Tampang $T$ dengan Perkuatan Wire Rope pada daerah momen Negatif menggunakan Program response-2000 dan Metode Pias, Jurnal Teknik Sipil, 13 (3),173-180. 